\title{
Potential antioxidant retention and quality maintenance in raspberries and strawberries treated with calcium chloride and stored under refrigeration
}

\section{Potencial de retenção de antioxidante e manutenção de qualidade de framboesas e morangos tratados com cloreto de cálcio e estocados sob refrigeração}

\author{
Tamar Turmanidze ${ }^{1 *}$, Levan Gulua', Merab Jgenti', Louise Wicker ${ }^{2,3}$ \\ 1 Agricultural University of Georgia, Department of Food Technology, Kakha Bendukidze University Campus, Tbilisi - Georgia \\ 2 University of Georgia, Department of Food Science and Technology, Athens/GA - USA \\ ${ }^{3}$ Korea University, College of Education, Department of Home Economics Education, Seongbuk-Gu, Seoul - Republic of Korea
}

\section{*Corresponding Author}

Tamar Turmanidze, Agricultural University of Georgia, Department of Food Technology, Kakha Bendukidze University Campus, \#240 David Aghmashenebeli Alley, Tbilisi - Georgia, e-mail: tturm2010@agruni.edu.ge

Cite as: Potential antioxidant retention and quality maintenance in raspberries and strawberries treated with calcium chloride and stored under refrigeration. Braz. J. Food Technol., v. 20, e2016089, 2017.

Received: July 15, 2016; Accepted: Apr. 07, 2017

\section{Abstract}

Raspberry and strawberry fruits were stored at $0{ }^{\circ} \mathrm{C}$ and relative humidity $(\mathrm{RH})$ of $95 \%$ for eight days. The fruits were treated with calcium chloride and their quality parameters and weight loss monitored and compared with those of untreated ones. A higher weight loss was observed for the untreated raspberries (16\%) than for the fruits treated with $2 \%$ calcium chloride (5.3\%). Similarly, untreated strawberry fruits lost more weight (8.5\%) than those treated with $2 \%$ calcium chloride only $4.1 \%$. The application of calcium chloride did not significantly influence the total acid content of the fruits. After 8 days storage the total soluble solids (TSS) had decreased to $10.22 \pm 0.06,9.60 \pm 0.05$ and $9.65 \pm 0.12$ in the raspberry fruits treated with $0 \%, 1 \%$ and $2 \%$ calcium chloride, respectively, and to $7.00 \pm 0.17,6.57 \pm 0.08$ and $6.35 \pm 0.04$ in the strawberry fruits treated with $0 \%, 1 \%$ and $2 \%$ calcium chloride, respectively. After storage, the ascorbic acid contents were significantly $(p \leq 0.05)$ higher in samples of raspberry and strawberry fruits subjected to $2 \%$ calcium chloride dips. The $\mathrm{CaCl}_{2}$ treatments had a significant effect on retaining the ascorbic acid contents in these fruits. The treatment of raspberry and strawberry fruits with calcium chloride had a positive effect $(p<0.05)$ on the retention of the total phenolic contents (TPC) during the storage period. $66 \%$ and $74 \%$ of the antioxidant potentials were retained in the untreated samples of raspberries and strawberries, as against $78 \%$ and $89 \%$ in the $2 \%$ calcium chloride treated samples of these fruits.

Keywords: Raspberry; Strawberry; Calcium chloride; Storage.

\section{Resumo}

Frutos de framboesa e de morango foram armazenados a $0{ }^{\circ} \mathrm{C}$ e umidade relativa (UR) de $95 \%$ durante oito dias. Os frutos foram tratados com cloreto de cálcio e seus parâmetros de qualidade e perdas de peso monitorados e comparados com os valores dos frutos não tratados. Uma perda de peso maior foi observada para as framboesas não tratadas (16\%) que para os frutos tratados com $2 \%$ de cloreto de cálcio (5,3\%). Similarmente, os frutos de morango não tratados perderam mais peso (8,5\%) que aqueles tratados com $2 \%$ de cloreto de cálcio - apenas $4,1 \%$. A aplicação de cloreto de cálcio não influenciou significativamente no conteúdo total de ácido dos frutos. Depois de 8 dias de estocagem, o teor de sólidos totais (TST) diminuiu para 10,22 \pm 0,06, 9,60 $\pm 0,05$ e 9,65 $\pm 0,12$ nos frutos de framboesa tratados com $0 \%, 1 \%$ e $2 \%$ cloreto de cálcio, respectivamente, e para 7,00 $\pm 0,17,6,57 \pm 0,08$ e 6,35 $\pm 0,04$ nos frutos de morango tratados com $0 \%, 1 \%$ e $2 \%$ de cloreto de cálcio, respectivamente. Depois da estocagem, o conteúdo de ácido ascórbico foi significativamente $(p \leq 0,05)$ mais alto nas amostras de frutos de framboesa e morango sujeitos à imersão em $2 \%$ de cloreto de cálcio. Os tratamentos com $\mathrm{CaCl}_{2}$ tiveram um efeito significativo na retenção de ácido ascórbico nestes frutos. $O$ tratamento dos frutos de framboesa e morango com cloreto de cálcio teve um efeito positivo $(p<0,05)$ na retenção do conteúdo total de fenólicos (CTF) durante o período de estocagem. Do potencial de antioxidante, $66 \%$ e $74 \%$ foram retidos nas amostras não tratadas de framboesa e morango contra $78 \%$ e $89 \%$ nas amostras destes frutos tratados com $2 \%$ de cloreto de cálcio.

Palavras-chave: Framboesa; Morango; Cloreto de cálcio; Estocagem. 
Turmanidze, T. et al.

\section{Introduction}

Berries, especially raspberry (Rubus Idaeus L. cv. Killarney) and strawberry (Fragaria $\mathrm{x}$ ananassa. cv. Red Dream), members of the family Rosaceae, belong to the best dietary sources of bioactive compounds (BAC) (SKROVANKOVA et al., 2015; HALVORSEN et al., 2002; SOUZA et al., 2014; SLATNAR et al., 2012; NAMIESNIK et al., 2014; DIACONEASA et al., 2015). They have a delicious taste and flavour, economic importance, and antioxidant properties from the BAC (SKROVANKOVA et al., 2015). The BAC in berries contain mainly phenols (KATSUBE et al., 2003; GIOVANELLI; BURATTI, 2009; PRIOR et al., 1998; REMBERG et al., 2006)

Phenolic compounds may contribute to this protective effect. Berries are very rich in health-promoting phytochemicals (FORTALEZAS et al., 2010) and many of these phytochemicals have antioxidant activity and may help protect cells against the oxidative damage caused by free radicals (WADA; OU, 2002; PRIOR, 2003; ICHIYANAGI et al., 2014; ZHENG; WANG, 2003; PANICO et al., 2009). Berries can be used in the development of functional foods with the objective of enhancing the health conditions (POTTER et al., 2009). Berry antioxidants may prevent some crucial points in the genesis of carcinomas (LOBO et al., 2010; LIMBERAKI et al., 2012; KÅRLUND et al., 2014; STAINMETZ; POTTER, 1991; AMES et al., 1993). Different berries and berry phenolic compounds also possess considerable antimicrobial effects against organisms such as Salmonella and Staphylococcus (PUUPPONEN-PIMIÄ et al., 2005; BURDULIS et al., 2009).

However, raspberry and strawberry are also highly perishable fruit due to their soft texture, high softening rate and great sensitivity to fungal attack. The quality declines rapidly after harvest, which must be done at full maturity, and the storage life may be less than a week (WILLS, 1998), so to overcome this problem raspberry and strawberry fruits may be treated with calcium chloride (ASTUTI et al., 2013).

Calcium is a divalent cation that readily enters the apoplast and is bound to the cell wall and exterior surface of the plasma membrane in an exchangeable form. Calcium maintains the cell wall structure of the fruit by interacting with the pectic acid in the cell walls to form calcium pectate. $\mathrm{Ca}^{2+}$ forms cross-links between pairs of negatively charged homogalacturonans, thus tightening the cell wall (PICCHIONI et al., 1998). The application of calcium postharvest maintains cell turgor, membrane integrity and tissue firmness, and delays membrane lipid catabolism, extending the storage life of the fresh fruits and reducing physiological disorders (GARCIA et al., 1996; POOVAIAH, 1986).

The increase of $\mathrm{Ca}$ content in the fruit tissue was accompanied by reductions in the respiration rate, ascorbic acid degradation and membrane lipid peroxidation, which enhanced the total phenolic content (TPC) and total antioxidant capacity (WANG et al., 2014). Significant increases in polyphenols and anthocyanins were registered during storage, with a resulting increase in total antioxidant activity (FADDA et al., 2015). The postharvest application of $\mathrm{CaCl}_{2}$ at appropriate rates imparts no detrimental effect on consumer acceptance of the treated fruit (LESTER; GRUSAK, 2001; SAFTNER et al., 1999).

The objective of the present study was to investigate the effect of the calcium treatment on berry fruits with respect to retaining the ascorbic acid and anthocyanins, TPC, antioxidant activity and also other general quality parameters during the storage period.

\section{Material and methods}

\subsection{Chemicals}

Ascorbic acid higher than $99.0 \%$ and potassium dihydrogen phosphate were purchased from Sigma-Aldrich (Steinheim, Germany); TPTZ - 2-4-6-tris (2-pyridyl)-s-triazine (Sigma-Aldrich, Switzerland), the Folin-Ciocalteau reagent (Appli Chem, Germany), hydrochloric acid, formic acid and phosphoric acid were provided by Merck (Darm-stadt, Germany); sodium carbonate was purchased from ChemCruz (ChemCruz Biochemicals, USA); ethyl acetate and methanol (Sigma-Aldrich, Steinheim, Germany) were HPLC grade. All other reagents were commercially available at the local market and were of analytical grade.

\subsection{Sample collection}

The strawberries and raspberries were harvested in mid-summer in the eastern part of Georgia (GPS coordinates:

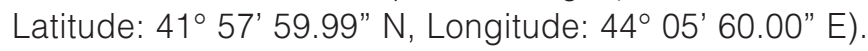
Quality parameters such as weight loss, vitamin C content, TPC and anthocyanin content, as well as the antioxidant potential were monitored at the start of sampling and after 8 days of storage at $0{ }^{\circ} \mathrm{C}$. After $8-10$ days most fruits were mouldy and damaged and the study was discontinued.

After harvesting, representative samples of the fruits were treated with $0 \%, 1 \%$ or $2 \%$ calcium chloride solution at $20 \pm 1^{\circ} \mathrm{C}$ with an exposure time of $2.5 \mathrm{~min}$. The treated samples were stored for 8 days in a refrigerator at $0 \pm 0.5^{\circ} \mathrm{C}$ and $95 \pm 0.5 \% \mathrm{RH}$.

\subsection{Sampling procedure}

The samples were prepared for the ascorbic acid determination by HPLC (Varian-Prostar-500, USA, detector-UV varian Prostar, Australia, column- $250 \mathrm{~mm} \times 4.6 \mathrm{~mm}$, $\mathrm{dp}=5 \mu \mathrm{m}$ (Symmetry, Waters, Ireland) (KOYUNCU; DILMAGUUNNAL, 2010) as follows: briefly, the sample $(10 \mathrm{~g})$ was extracted in $10 \mathrm{~mL}$ water adjusted to $\mathrm{pH} 1.5$ with $10 \mathrm{~mL}$ phosphoric acid-water (2\%, v/v). The extracts were filtered through $45 \mu \mathrm{m}$ filter paper (Whatman, UK) 
Potential antioxidant retention and quality maintenance in raspberries and strawberries treated with calcium chloride and stored under refrigeration

Turmanidze, T. et al.

and $1.5 \mathrm{~mL}$ buffer $\left(0.01 \mathrm{M} \mathrm{KH}_{2} \mathrm{PO}_{4}, \mathrm{pH} 8.0\right)$ then added to $1.5 \mathrm{~mL}$ of the sample extract. $1 \mathrm{~mL}$ aliquots (vitamin $\mathrm{C}$ ) of each of the preferred mixtures were then loaded on to $C 18$ cartridges (Agilent, Bond Elut, USA) and $3 \mathrm{~mL}$ aliquots of water adjusted to $\mathrm{pH} 1.5$ with $2 \mathrm{~mL}$ phosphoric acid-water $(2 \%, v / v)$ passed through them.

The samples used for the antioxidant analysis were prepared according to Rodriguez-Saona and Wrolstad (2001). About $40 \mathrm{~g}$ of strawberries and raspberries were cryogenically milled in liquid nitrogen. Chilled test tubes were filled with milled fruit powder and weighed $(5 \mathrm{~g})$, and the powder then extracted with acetone $(200 \mathrm{~mL})$. The acetone was removed under vacuum in a rotary evaporator at $<30{ }^{\circ} \mathrm{C}$, and $250 \mathrm{~mL}$ of methanol $(70 \%)$ then added to the powder. The total methanol extract was examined for antioxidant activity.

The titratable acidity (TA) was determined by titration with $0.1 \mathrm{~N} \mathrm{NaOH}$ to a pink colour using $1 \%$ phenolphthalein as indicator and expressed as $\mathrm{g} / 100 \mathrm{~g}$ citric acid (MORRIS et al., 1985). The TSS were measured by digital refractometer (WYA -2S, China).

Vitamin C was determined by the HPLC method (KOYUNCU; DILMAGUUNNAL, 2010). The columns used were $250 \mathrm{~mm} \times 4.6 \mathrm{~mm}, \mathrm{dp}=5 \mu \mathrm{m}$ (Symmetry, Waters, Ireland) and the mobile phase was water adjusted to $\mathrm{pH} 3$ with phosphoric acid. The UV detector (Varian pro Star, Australia) was set at $215 \mathrm{~nm}$ and quantification was based on the peak area measurement. For HPLC (Varian-Prostar-500, USA), $20 \mu \mathrm{L}$ of sample were injected.

The anthocyanins were quantified by the $\mathrm{pH}$ differential method (GIUSTI; WROLSTAD, 2001). Samples were diluted 1:150 in $\mathrm{pH} 1.0$ and $\mathrm{pH} 4.5$ buffers, and the absorbance measured at $520 \mathrm{~nm}$ and $700 \mathrm{~nm}$ in a UV -Visible spectrophotometer (A \& E Lab Co LTD, UK), based on a cyanidin 3-glucoside molar extinction coefficient of $26,900 \Delta \mathrm{E} / \mathrm{mol}$ and a molecular weight of $449.2 \mathrm{~g} / \mathrm{mol}$. The resulting values were expressed in terms of $\mathrm{mg}$ of anthocyanin per $100 \mathrm{~g}$ of fresh fruit.

The Total phenolic compound content (BOND et al., 2003) was determined using a $1.0 \mathrm{~mL}$ aliquot of diluted sample extract, which was vortexed with $10 \mathrm{~mL}$ deionized (DI) water and $1.0 \mathrm{~mL}$ Folin-Ciocalteau reagent, and
$1.0 \mathrm{~mL}$ deionized water was used as the control. After equilibrating at room temperature for $8 \mathrm{~min}$, the solutions were mixed with $4 \mathrm{~mL}$ of $7.5 \%(\mathrm{w} / \mathrm{v}) \mathrm{Na}_{2} \mathrm{CO}_{3}$. The samples and standards (dilute gallic acid standard working solutions: $10-50 \mu \mathrm{g} / \mathrm{mL}$ ) were equilibrated at room temperature for 60 minutes. The absorbance values of the samples and standards were measured spectrophotometrically (UV/Vis spectrophotometer, A\&E Lab Co LTD, UK) at $765 \mathrm{~nm}$, with a $10 \mathrm{~mm}$ path length cell and the TPC was calculated as mg of gallic acid equivalents per 100 gram fresh sample weight.

The Ferric Reducing Ability of Plasma (FRAP) assay was carried out as previously described by Benzie and Strain (1996). The experiment was carried out at $37^{\circ} \mathrm{C}$ and $\mathrm{pH} 3.6$ with a blank sample in parallel. In the FRAP assay, the reductants ("antioxidants") in the sample reduce the Fe (III)/tripyridyltriazine complex to the blue ferrous form, with an increase in absorbance at $593 \mathrm{~nm}$. The final results were expressed as micromole ascorbic acid (AA) equivalents per 100 gram (mmol AA/ $100 \mathrm{~g}$ ).

\subsection{Statistical analysis}

The data represent the mean of three replicates \pm standard deviation (SD) and were subjected to ANOVA analyses. All calculations were carried out using Microsoft Excel 2007 (Microsoft Corp., Redmond, WA, USA) with PHstat 2 version 3.11add-in assistance.

\section{Results and discussion}

\subsection{Weight loss}

Fruit weight loss is associated with respiration and moisture evaporation through the skin. The data in Table 1 show that during storage $\left(0^{\circ} \mathrm{C}\right.$ and $\left.95 \pm 0.5 \% \mathrm{RH}\right)$ the raspberry fruits lost from 5.3 to $16 \%$ of their weight depending on the calcium treatment. The maximum loss was observed for the untreated fruits (16\%) and the minimum loss for the fruits treated with $2 \%$ calcium chloride (5.3\%). Similarly, untreated strawberry fruits lost a maximum weight of $8.5 \%$ and fruits treated with $2 \%$ calcium chloride only lost $4.1 \%$, which is more than two times less than the untreated fruits.

Table 1. The effect of calcium chloride treatment on the weight loss of berries during 8 days of storage $\left(\right.$ at $\left.0 \pm 0.5{ }^{\circ} \mathrm{C}, \mathrm{RH} 95 \pm 0.5 \%\right)$.

\begin{tabular}{ccccc} 
Berry & $\begin{array}{c}\text { Treatments } \\
(\%, \text { calcium chloride) }\end{array}$ & $\begin{array}{c}\text { Initial weight } \\
(\mathbf{g})\end{array}$ & $\begin{array}{c}\text { Weight after storage } \\
(\mathbf{g})\end{array}$ & $\begin{array}{c}\text { Weight loss } \\
(\%)\end{array}$ \\
Raspberry & 0 & $14.22 \pm 0.14$ & $11.92 \pm 0.01$ & $16.00 \pm 0.04$ \\
& 1 & $11.71 \pm 0.05^{\mathrm{a}}$ & $10.64 \pm 0.07^{\mathrm{a}}$ & $9.10 \pm 0.01^{\mathrm{a}}$ \\
Strawberry & 2 & $12.48 \pm 0.02^{\mathrm{b}}$ & $11.81 \pm 0.03^{\mathrm{b}}$ & $5.30 \pm 0.04^{\mathrm{b}}$ \\
& 0 & $18.90 \pm 0.10$ & $17.29 \pm 0.08$ & $8.50 \pm 0.07$ \\
& 1 & $21.01 \pm 0.12^{\mathrm{a}}$ & $19.74 \pm 0.14^{\mathrm{a}}$ & $6.00 \pm 0.01^{\mathrm{a}}$ \\
\hline
\end{tabular}

The data represent the mean of three replicates \pm SD; a,b differences between test and control samples in the same column are statistically significant. 
Potential antioxidant retention and quality maintenance in raspberries and strawberries treated with calcium chloride and stored under refrigeration

Turmanidze, T. et al.

The lower weight loss in samples treated with the calcium chloride dip may be due to increased water holding by the formation of calcium pectate hydrogel, and a delay in the dehydration process (Table 1). One-way ANOVA analyses for the raspberry and strawberry fruits showed statistically significant differences between the mean values for weight loss of the 0,1 and $2 \%$ treatment groups $(p<0.05)$.

\subsection{TA and TSS}

The TA of the untreated raspberries and strawberries decreased from $2.34 \pm 0.05$ to $1.71 \pm 0.02$ and from $0.81 \pm 0.03$ to $0.70 \pm 0.03$, respectively during the days of storage. The application of calcium chloride did not significantly influence this parameter (Table 2).

The initial TSS content was $11.00 \pm 0.08$ and $8.55 \pm 0.15$ for raspberry and strawberry fruits, respectively.

After 8 days storage the TSS decreased to $10.22 \pm 0.06$, $9.60 \pm 0.05$ and $9.65 \pm 0.12$ in the raspberry fruits treated with $0 \%, 1 \%$ and $2 \%$ calcium chloride respectively and to $7.00 \pm 0.17,6.57 \pm 0.08$ and $6.35 \pm 0.04$ in the strawberry fruits treated with $0 \%, 1 \%$ and $2 \%$ calcium chloride respectively. In general, a decrease in TSS is associated with the respiration process in fruits. The slightly lower TSS in the $1 \%$ and $2 \%$ calcium chloride treated samples might be due to inhibition by the calcium chloride of the enzymatic conversion of higher polysaccharides, such as starches and pectins, into simple sugars (HUSSAIN et al., 2008).

\subsection{Ascorbic acid content}

Ascorbic acid is an important nutrient and is very sensitive to degradation by oxidation during food processing and storage, as compared to other nutrients (VELTMAN et al., 2000). The initial contents of ascorbic acid in the raspberry and strawberry fruits were, respectively, $23.87 \pm 0.35$ and $45.17 \pm 0.24 \mathrm{mg}$ per $100 \mathrm{~g}$ of fruits. Eight days of storage resulted in oxidative degradation of the ascorbic acid down to $12.98 \pm 0.12(54 \%)$ and $27.35 \pm 0.35$ $(77 \%) \mathrm{mg}$ per $100 \mathrm{~g}$ of untreated raspberry and strawberry fruits, respectively (Table 2.). After storage, the ascorbic acid contents were significantly $(p \leq 0.05)$ higher in the raspberry and strawberry fruit samples subjected to a $2 \%$ calcium chloride dip.

These results showed that $\mathrm{CaCl}_{2}$ treatments had a significant effect on retaining the ascorbic acid contents of these fruits. This might be because higher concentrations of $\mathrm{CaCl}_{2}$ delayed the rapid oxidation of ascorbic acid in the samples.

For all 6 stored groups in Table 2, one-way ANOVA analyses showed there was strong evidence to reject the null hypothesis $(p<0.05)$.

\subsection{TPC and Anthocyanin content}

The treatment of raspberry and strawberry fruits with calcium chloride had a positive effect $(p<0.05)$ on TPC retention during the storage period (Table 3 ). This might be because the addition of calcium chloride to the fruits strengthened the cell wall, enhancing the formation of an egg box structure and minimized syneresis/leaching of water soluble compounds such as polyphenols. The most important polyphenols of strawberries and raspberries are anthocyanins, and the main anthocyanin of strawberries is pelargonidin 3-O-monoglucoside and that of raspberries is cyanidin-3-O-monoglucoside (SKROVANKOVA et al., 2015). The data in Table 3 shows that the total anthocyanins in the untreated sample of raspberry were reduced by $30 \%$ during storage, whereas in the $1 \%$ and $2 \%$ calcium treated samples the total anthocyanins were only reduced by $12 \%$ and $15 \%$, respectively. For the strawberry fruits the reduction in anthocyanins in the untreated sample was $23 \%$, whereas in the $1 \%$ and $2 \%$ calcium treated strawberry samples the total anthocyanin reduction was only $19 \%$ and $15.5 \%$, respectively.

\subsection{Antioxidant potential}

Polyphenols and ascorbic acid are the two main contributors of antioxidant activity in fruits. Since both of these were degraded during the storage period, the antioxidant potential of fruits was also reduced. Table 3 shows

Table 2. Effect of calcium chloride treatment on the quality parameters of berries during storage (at $0 \pm 0.5^{\circ} \mathrm{C}, \mathrm{RH} 95 \pm 0.5 \%$ ).

\begin{tabular}{cccccc} 
Berry & $\begin{array}{c}\text { Storage period } \\
\text { (days) }\end{array}$ & $\begin{array}{c}\text { Treatments } \\
\text { (\%, calcium } \\
\text { chloride) }\end{array}$ & $\begin{array}{c}\text { TSS } \\
\mathbf{( \% )}\end{array}$ & $\begin{array}{c}\text { TA } \\
(\%)\end{array}$ & $\begin{array}{c}\text { Vitamin C } \\
(\mathbf{m g} / \mathbf{1 0 0} \mathbf{g})\end{array}$ \\
Raspberry & 0 & 0 & $11.00 \pm 0.08$ & $2.34 \pm 0.05$ & $23.87 \pm 0.35$ \\
& 8 & 1 & $10.22 \pm 0.06$ & $1.71 \pm 0.08$ & $12.98 \pm 0.12$ \\
& 8 & 2 & $9.60 \pm 0.05^{\mathrm{a}}$ & $1.76 \pm 0.02^{\mathrm{a}}$ & $14.96 \pm 0.25^{\mathrm{a}}$ \\
& 8 & fresh & $9.65 \pm 0.12^{\mathrm{b}}$ & $1.77 \pm 0.02^{\mathrm{b}}$ & $17.05 \pm 0.31^{\mathrm{b}}$ \\
Strawberry & 0 & 0 & $8.55 \pm 0.15$ & $0.81 \pm 0.02$ & $45.17 \pm 0.24$ \\
& 8 & 1 & $7.00 \pm 0.17$ & $0.72 \pm 0.03$ & $27.35 \pm 0.35$ \\
& 8 & 2 & $6.57 \pm 0.08^{\mathrm{a}}$ & $0.67 \pm 0.02^{\mathrm{a}}$ & $29.85 \pm 0.17^{\mathrm{a}}$ \\
\hline
\end{tabular}

The data represents the mean of three replicates \pm SD; a,b differences between test and control samples within the columns are statistically significant. 
Potential antioxidant retention and quality maintenance in raspberries and strawberries treated with calcium chloride and stored under refrigeration

Turmanidze, T. et al.

Table 3. Effect of calcium chloride treatments on the TPC, monomeric anthocyanin contents and FRAP of berries during storage (at $0 \pm 0.5^{\circ} \mathrm{C}, \mathrm{RH} 95 \pm 0.5 \%$ )

\begin{tabular}{cccccc} 
Berry & $\begin{array}{c}\text { Storage period } \\
\text { (days) }\end{array}$ & $\begin{array}{c}\text { Treatments } \\
\text { (\%, calcium } \\
\text { chloride) }\end{array}$ & $\begin{array}{c}\text { TPC } \\
\text { (mg/100 g) }\end{array}$ & $\begin{array}{c}\text { Monomeric } \\
\text { anthocyanins } \\
\text { (mg/100 g) }\end{array}$ & $\begin{array}{c}\text { FRAP } \\
\text { (mg equivalents } \\
\text { vitamin } \mathbf{~} / \mathbf{1 0 0} \mathbf{g})\end{array}$ \\
Raspberry & 0 & fresh & $116.01 \pm 1.25$ & $33.34 \pm 0.52$ & $220.00 \pm 3.56$ \\
& 8 & 0 & $105.58 \pm 2.41$ & $23.35 \pm 0.42$ & $146.63 \pm 4.23$ \\
& 8 & 1 & $113.38 \pm 2.20^{\mathrm{a}}$ & $29.26 \pm 0.15^{\mathrm{a}}$ & $173.72 \pm 3.65^{\mathrm{a}}$ \\
& 8 & 2 & $109.98 \pm 1.65^{\mathrm{b}}$ & $27.88 \pm 0.71^{\mathrm{b}}$ & $167.70 \pm 4.82^{\mathrm{b}}$ \\
Strawberry & 0 & fresh & $152.94 \pm 2.45$ & $63.87 \pm 0.51$ & $413.10 \pm 3.52$ \\
& 8 & 0 & $130.60 \pm 2.75$ & $49.29 \pm 1.42$ & $306.08 \pm 4.95$ \\
& 8 & 1 & $136.13 \pm 3.85^{\mathrm{a}}$ & $52.17 \pm 0.98^{\mathrm{a}}$ & $357.19 \pm 2.75^{\mathrm{a}}$ \\
& 8 & 2 & $145.37 \pm 3.15^{\mathrm{b}}$ & $54.34 \pm 1.05^{\mathrm{b}}$ & $368.75 \pm 4.32^{\mathrm{b}}$ \\
\hline
\end{tabular}

The data represents the mean of three replicates \pm SD; a,b differences between test and control samples within the columns are statistically significant.

that the initial antioxidant potentials of the raspberry and strawberry fruits were $220.00 \pm 3.56$ and $413.10 \pm 3.52 \mathrm{mg}$ ascorbic acid equivalents per $100 \mathrm{~g}$ fruits, respectively. The calcium chloride treatment had a positive effect on retaining the antioxidant potential in both fruit samples. In the untreated samples of raspberry and strawberry, $66 \%$ and $74 \%$ of the antioxidant potentials were retained, respectively, whereas in the treated samples, the maximum antioxidant potentials retained were $78 \%$ and $89 \%$ in the raspberry and strawberry fruits, respectively. This was evidently due to the positive effect of the calcium chloride treatment on retaining the ascorbic acid and polyphenols in the fruits. One-way ANOVA analyses were carried out for all six stored groups shown in Table 3 . The results indicated statistically significant differences between the mean values inside the groups. The differences between the test and control samples are shown in Table 3.

\section{Conclusions}

The application of a calcium chloride dip to fresh raspberry and strawberry fruits did not negatively influence quality factors such as TA and TSS, but the ascorbic acid content was higher in the calcium chloride treated berries. The TPC and antioxidant potential in stored fruit was higher if treated with calcium chloride. The calcium chloride treatment also had a positive effect on retaining monomeric anthocyanins during storage. A calcium chloride dip is a practical way to extend the shelf life and nutritional quality of raspberries and strawberries during chilled storage.

\section{Acknowledgements}

The authors declare no conflicts of interest. The research was carried out in the framework of the research task financed by Shota Rustaveli National Science Foundation (SRNSF), nº AR/94/10-160/13.

\section{References}

AMES, B. N.; SHIGENAGA, M. K.; HAGEN, T. M. Oxidants, antioxidants, and the degenerative diseases of aging. Proceedings of the National Academy of Sciences of the United States of America, Washington, DC, v. 90, n. 17, p. 7915-7922, 1993. http://dx.doi.org/10.1073/pnas.90.17.7915

ASTUTI, N. K.; MAGHFOER, M. D.; SOELISTYONO, R. Calcium chloride applications to improve fruit quality on bruised and diseased of pineapple (Ananas comosos (L) Merr). IOSR Journal of Applied Chemistry, Bangladesh, v. 5, p. 30-34, 2013.

BENZIE, I. F. F.; STRAIN, J. J. The ferric reducing ability of plasma (FRAP) as a measure of "antioxidant power": the FRAP assay. Analytical Biochemistry, Maryland Heights, v. 239, p. 70-76, 1996.

BOND, T. J.; LEWIS, J. R.; DAVIS, A.; DAVIS, A. P. Analysis and purification of catechins and their transformation products. In: SANTOS-BULGA, C., WILLIAMSON, G. (Ed.). Methods of polyphenols analysis. London: The Royal Society of Chemistry, 2003. Chap. 11.

BURDULIS, D.; ŠARKINAS, A.; JASUTIENĖ, I.; STACKEVIČIENĖ, E.; NIKOLAJEVAS, L.; JANULIS, V. Comparative study of anthocyanin composition antimicrobial and antioxidant activity in bilberry (Vaccinium myrtillus L.) and Bluberry (Vaccinium corymbosum L.) fruits. Acta Poloniae Pharmaceutica, Warszawa, v. 66, n. 4, p. 399-408, 2009.

DIACONEASA, Z.; RANGA, F.; RUGINǍ, D.; LEOPOLD, L.; POP, O.; VODNAR, D.; CUIBUS, L.; SOCACIU, C. Phenolic content and their antioxidant activity in various berries cultivated in Romania. Journal of Food Science and Technology, Oxford, v. 72, n. 1, p. 99-103, 2015.

FADDA, C.; FENU, P. A. M.; USAI, G.; CARO, A. D.; DIEZ, Y. M.; SANGUINETTI, A. M.; PIGA, A. Antioxidant activity and sensory changes of strawberry tree fruits during cold storage and shelf life. Czech Journal of Food Science, Czech Republic, v. 33, n. 6, p. 531-536, 2015. http://dx.doi.org/10.17221/171/2015-CJFS. 
Potential antioxidant retention and quality maintenance in raspberries and strawberries treated with calcium chloride and stored under refrigeration

Turmanidze, T. et al.

FORTALEZAS, S.; TAVARES, L.; PIMPAO, R.; TYAGI, M.; PONTES, V.; ALVES, P. M.; MCDOUGALL, G.; STEWART, D.; FERREIRA, R.B.; SANTOS, C.N. Antioxidant properties and neuroprotective capacity of strawberry tree fruit (Arbutus unedo). Nutrition, United States, v. 2, p. 214-229, 2010.

GARCIA, J. M.; HERRERA, S.; MORILLA, A. Effects of postharvest dips in calcium chloride on strawberry. Journal of Agricultural and Food Chemistry, Washington, DC, v. 44, p. 30-33, 1996.

GIOVANELLI, G.; BURATTI, S. Comparison of polyphenolic composition and antioxidant activity of wild Italian blueberries and some cultivated varieties. Food Chemistry, London, v. 112, p. 903-908, 2009.

GIUSTI, M. M.; WROLSTAD, R. E. Characterization and measurement with UV visible spectroscopy. In: WROLSTAD, R. E. (Ed.). Current protocols in food analytical chemistry. Hoboken: John Wiley \& Sons, 2001.

HALVORSEN, B. L.; HOLTE, K.; MYHRSTAD, M. C.; BARIKMO, I.; HVATTUM, E.; REMBERG, S. F.; WOLD, A. B.; HAFFNER, K.; BAUGEROD, H.; ANDERSEN, L. F. A systematic screening of total antioxidants in dietary plants. Journal of Nutrition, United States, v. 132, p. 461-471, 2002.

HUSSAIN, P. R.; DAR, M. A.; MENNA, R. S.; MIR, M. A.; SNAFI, F.; WANI, A. M. Changes in quality of apple (Malus domestica) cultivars due to gamma irradiation and storage conditions. Journal of Food Science and Technology, Oxford, v. 45, p. 444-449, 2008.

ICHIYANAGI, T.; HATANO, Y.; MATSUO, S.; KONISHI, T. Simultaneous comparison of relative reactivities of twelve major anthocyanins in bilberry towards reactive nitrogen species. Chemical and Pharmaceutical Bulletin, Tokyo, v. 52, p. 1312-1315, 2014.

KÅRLUND, A.; MOOR, U.; SANDELL, M.; KARJALAINEN, R. O. The impact of harvesting, storage and processing factors on health-promoting phytochemicals in berries and fruits. Processes, Basel, v. 2, p. 596-624, 2014.

KATSUBE, N.; IWASHITA, K.; TSUSHIDA, T.; YAMAKI, K.; KOBORI, $M$. Induction of apoptosis in cancer cells by bilberry (Vaccinium myrtillus) and the anthocyanins. Journal of Agricultural and Food Chemistry, Washington, DC, v. 51, p. 68-75, 2003.

KOYUNCU, M. A.; DILMAĢÜNAL, T. Determination of vitamin C and organic acid changes in strawberry by HPLC during cold storage. Notulae Botanicae Horti Agrobotanici, Cluj-Napoca, v. 38, n. 3, p. 95-98, 2010.

LESTER, G. E.; GRUSAK, M. A. Postharvest application of chelated and nonchelated calcium dip treatments to commercially grown honey dew melons: effects on peel attributes, tissue calcium concentration, quality, and consumer preference following storage. Hort Technology, Alexandria, v. 11, p. 561-566, 2001.

LIMBERAKI, E.; ELEFTHERIOU, P.; VAGDATLI, E.; KOSTOGLOU, V.; PETROU C. Serum antioxidant status among young, middle- aged and elderly people before and after antioxidant rich diet. Hippokratia, Thessaloniki, v. 16, 118-123, 2012.

LOBO, V.; PATIL, A.; PHATAK, C. N. Free radicals, antioxidants and functional foods: impact on human health. Pharmacological Reviews, Bethesda, v. 4, 118-126, 2010.

MORRIS, J. R.; SISTRUNK, W. A.; SIMS, C. A.; MAIN, G. L.; WEHUNT, E. J. Effects of cultivar, postharvest storage, preprocessing dip treatments and style of pack on the processing quality of strawberries. Journal of Horticultural Sciences, Banglore, v. 110, p. 172-177, 1985.

NAMIESNIK, J.; VEARASILP, K.; NEMIROVSKI, A.; LEONTOWICZ, H.; LEONTOWICZ, M.; PASKO, P.; MARTINEZ-AYALA, A. L.; GONZÁLEZ-AGUILAR, G. A.; SUHAJ, M.; GORINSTEIN, S. In vitro studies on the relationship between the antioxidant activities of some berry extracts and their binding properties to serum albumin. Applied of Biochemistry and Biotechnology, United States, v. 182, p. 2849-2865, 2014.

PANICO, A. M.; GARUFI, F.; NITTO, S.; DI MAURO, R.; LONGHITANO, R. C.; MAGRÌ, G. A.; CATALFO, A.; SERRENTINO, M. E.; GUIDI, G. Antioxidant activity and phenolic content of strawberry genotypes from Fragaria $x$ ananassa. Pharmaceutical Biology, United Kingdom, v. 47, n. 3, p. 203-208, 2009. http:// dx.doi.org/10.1080/13880200802462337.

PICCHIONI, G. A.; WATADA, A. E.; CONWAY, W. S.; WHITAKER, B.; SAMS, C. E. Postharvest calcium infiltration delays membrane lipid catabolism in apple fruit. Journal of Agricultural and Food Chemistry, Washington, v. 46, p. 2452-2457, 1998.

POOVAIAH, B. W. Role of calcium in prolonging storage life of fruits and vegetables. Food Technology, Chicago, v. 40, n. 5 , p. 86-89, 1986.

POTTER, R. M.; DOUGHERTY, M. P.; HALTEMAN, W. A.; CAMIRE, M. E. Characteristics of wild blueberry-soy beverages. Food Science and Technology, Washington, DC, v. 40, p. 807-814, 2009.

PRIOR, R. L. Fruits and vegetable in the prevention of cellular oxidative damage. The American Journal of Clinical Nutrition, Bethesda, v. 78, p. 570s-578s, 2003.

PRIOR, R. L.; CAO, G.; MARTIN, A.; SOFIC, E.; MCEWEN, J.; O'BRIEN, C.; LISCHNER, N.; EHLENFELDT, M.; KALT, W.; KREWER, G.; MAINLAND, C. M. Antioxidant capacity as influenced by total phenolic and anthocyanin content, maturity, and variety of vaccinium species. Journal of Agricultural and Food Chemistry, Washington, DC, v. 46, p. 2686-2693, 1998.

PUUPPONEN-PIMIÄ, R.; NOHYNEK, L.; HARTMANN-SCHMIDLIN, S.; KÄHKÖNEN, M.; HEINONEN, M.; MAATTA-RIIHINEN, K.; OKSMAN-CALDENTEY, K. M. Berry phenolics selectively inhibit the growth of intestinal pathogens. Journal of Applied Microbiology, England, v. 98, p. 991-1000, 2005.

REMBERG, S. F.; WOLD, A. B.; KVAAL, K.; APPELGREN, M.; HAFFNER, K. An approach towards rapid optical measurements 
Potential antioxidant retention and quality maintenance in raspberries and strawberries treated with calcium chloride and stored under refrigeration

Turmanidze, T. et al.

of antioxidant activity in blueberry cultivars. Journal of Applied Botany and Food Quality, Quedlinburg, v. 80, p. 36-39, 2006.

RODRIGUEZ-SAONA, L. E.; WROLSTAD, R. E. Extraction, isolation and purification of Anthocyanins. In: WROLSTAD, R. E. (Ed.). Current protocols in food analytical chemistry. Hoboken: John Wiley \& Sons, 2001.

SAFTNER, R. A.; CONWAYM, W. S.; SAMS, C. E. Postharvest calcium infiltration alone and combined with surface coating treatments influence volatile levels, respiration, ethylene production, and internal atmospheres of 'Golden Delicious' apples. Journal of Horticultural Sciences, Banglore, v. 124, p. 553-558, 1999.

SKROVANKOVA, S.; SUMCZYNSKI, D.; MLCEK, J.; JURIKOVA, T.; SOCHOR, J. Bioactive compounds and antioxidant activity in different types of berries. International Journal of Molecular Sciences, Basel, v. 16, p. 24673-24706, 2015.

SLATNAR, A.; JAKOPIC, J.; STAMPAR, F.; VEBERIC, R.; JAMNIK, $P$. The effect of bioactive compounds on in vitro and in vivo antioxidant activity of different berry juices. PLoS ONE, San Francisco, v. 7, n. 10, p. e47880-1-e47880-8, 2012.

SOUZA, V. R.; PEREIRA, P. A.; SILVA, T. L.; LIMA, L. C. O.; PIO, R.; QUIROZ, F. Determination of the bioactive compounds, antioxidant activity and chemical composition of Brazilian blackberry, red raspberry, strawberry, blueberry and sweet cherry fruits. Food Chemistry, London, v. 156, p. 362-368, 2014.

STEINMETZ, K. A.; POTTER, J. D. Vegetables, fruit and cancer, I (Epidemiology). Cancer Causes and Control, Netherlands, v. 2, p. $427-442,1991$.

VELTMAN, R. H.; KHO, R. M. A.; VAN-SCHAIK, C. R.; SANDERS, M. G.; OOSTERHAVEN, J. Ascorbic acid and tissue browning in pears under controlled atmosphere conditions. Postharvest Biology and Technology, Amsterdam, v. 19, p. 129-137, 2000.

WADA, L.; OU, B. Antioxidant activity and phenolic content of oregon cranberries. Journal of Agricultural and Food Chemistry, Washington, DC, v. 50, p. 3495-3500, 2002.

WANG, Y.; XIE, X.; LONG, L. E. The effect of postharvest calcium application in hydro-cooling water on tissue calcium content, biochemical changes, and quality attributes of sweet cherry fruit. Food Chemistry, London, v. 160, p. 22-30, 2014.

WILLS, R. B. H. Enhancement of senescence in non-climacteric fruit and vegetables by low ethylene levels. Acta Horticulturae, Leuven, v. 464, p. 159-162, 1998.

ZHENG, W.; WANG, S. Y. Oxygen radical absorbing capacity of flavonoids and phenolic acids in blueberries, cranberries, chokeberries and lingonberries. Journal of Agricultural and Food Chemistry, Washington, DC, v. 51, p. 502-509, 2003. 